\title{
Effects of abrupt salinity increase on nitrification processes in freshwater moving bed
} biofilters

\author{
Kinyage, John Peter Hewa; Pedersen, Per Bovbjerg; Pedersen, Lars-Flemming
}

Published in:

Aquacultural Engineering

Link to article, DOI:

10.1016/j.aquaeng.2018.12.005

Publication date:

2019

Document Version

Peer reviewed version

Link back to DTU Orbit

Citation (APA):

Kinyage, J. P. H., Pedersen, P. B., \& Pedersen, L-F. (2019). Effects of abrupt salinity increase on nitrification processes in freshwater moving bed biofilters. Aquacultural Engineering, 84, 91-98.

https://doi.org/10.1016/j.aquaeng.2018.12.005

\section{General rights}

Copyright and moral rights for the publications made accessible in the public portal are retained by the authors and/or other copyright owners and it is a condition of accessing publications that users recognise and abide by the legal requirements associated with these rights.

- Users may download and print one copy of any publication from the public portal for the purpose of private study or research.

- You may not further distribute the material or use it for any profit-making activity or commercial gain

- You may freely distribute the URL identifying the publication in the public portal

If you believe that this document breaches copyright please contact us providing details, and we will remove access to the work immediately and investigate your claim. 


\section{Accepted Manuscript}

Title: Effects of abrupt salinity increase on nitrification processes in a freshwater moving bed biofilter

Authors: John Peter Hewa Kinyage, Per Bovbjerg Pedersen, Lars-Flemming Pedersen

PII:

DOI:

Reference:

To appear in:

Received date:

Revised date:

Accepted date:
S0144-8609(18)30094-3 https://doi.org/10.1016/j.aquaeng.2018.12.005 AQUE 1974

\section{Aquacultural Engineering}

\section{July 2018}

13 December 2018

15 December 2018

Please cite this article as: Kinyage JPH, Bovbjerg Pedersen P, Pedersen L-Flemming, Effects of abrupt salinity increase on nitrification processes in a freshwater moving bed biofilter, Aquacultural Engineering (2018), https://doi.org/10.1016/j.aquaeng.2018.12.005

This is a PDF file of an unedited manuscript that has been accepted for publication. As a service to our customers we are providing this early version of the manuscript. The manuscript will undergo copyediting, typesetting, and review of the resulting proof before it is published in its final form. Please note that during the production process errors may be discovered which could affect the content, and all legal disclaimers that apply to the journal pertain. 


\title{
Effects of abrupt salinity increase on nitrification processes in a freshwater moving bed biofilter
}

\author{
John Peter Hewa Kinyage ${ }^{a b^{*}}$, Per Bovbjerg Pedersen ${ }^{b}$ and Lars-Flemming Pedersen ${ }^{b}$ \\ a Sokoine University of Agriculture, Department of Animal, Aquaculture and Range Sciences, \\ Section of Aquaculture, Morogoro, Tanzania \\ ${ }^{b}$ Technical University of Denmark, National Institute of Aquatic Resources, DTU Aqua, Section of \\ Aquaculture, Hirtshals, Denmark \\ *Corresponding Author: Email Address; johnkinyage@yahoo.com
}

\begin{abstract}
The nitrification process is a widely used biological approach responsible for ammonia and nitrite removal in recirculating aquaculture system (RAS) biofilters. Given this pivotal role, the influence of different water quality parameter on nitrification efficiency is important information for RAS operations. One influencing parameter is salinity, and salinity fluctuations in freshwater RAS biofilters are reported to affect the nitrifying bacteria. This study investigated the effects of abrupt increase in salinity in freshwater RAS on substrate-dependent (1'-order) as well as substrate independent ( $0^{\prime}$-order) nitrification rates. A $100 \%$ inhibition was found for surface specific removal (STR) of total ammonia nitrogen (TAN) and surface specific nitrite removal (SNR) when salinity was abruptly increased to $25 \%$ and above. A fast turnover (i.e. steep decline in $\left[\mathrm{NH}_{4}-\mathrm{N}^{+}\right]$and $\left[\mathrm{NO}_{2}-\mathrm{N}^{-}\right]$) were observed at lower salinities $(\leq 10 \%$ ), while limited/no degradation of either ammonia or nitrite was seen at salinities above $25 \%$. At low substrate loading (1'-order process), removal rate constants $\left(k_{1 a}\right)$ of 0.22 and $0.23 \mathrm{~m} \cdot \mathrm{d}^{-1}$ were observed for ammonia and nitrite degradation, respectively, declining to $0.01 \mathrm{~m} \cdot \mathrm{d}^{-1}$ when adding marine RAS water increasing the salinity to $15 \%$. Similar observations followed at high nutrient loadings ( $0^{\prime}$-order process) with STR and SNR of 0.10 and $0.12 \mathrm{~g} \mathrm{~N} \cdot \mathrm{m}^{-2} \cdot \mathrm{d}^{-1}$, respectively, declining to $0.01 \mathrm{~g} \mathrm{~N} \cdot \mathrm{m}^{-2} \cdot \mathrm{d}^{-}$ ${ }^{1}$ at $15 \%$. When salinities of $25 \%$ ond $35 \%$ o were applied, neither TAN nor nitrite degradation was seen. The results thus demonstrate a pronounced effect of salinity changes when freshwater RAS biofilters are subjected to fast/abrupt changes in salinity. RAS facility operators should be aware of such potential effects and take relevant precautions.
\end{abstract}

Keywords: Nitrification, Salinity, RAS, Biofilter, STR, SNR, $k_{1 a}$ 


\section{Introduction}

Total ammonia nitrogen (TAN) and nitrite accumulation in recirculating aquaculture systems (RAS) poses risk to cultured organisms, and can be avoided by proper dimensioned biofilters and correct management (Eding et al., 2006; Rusten et al., 2006; Timmons and Ebeling, 2010; Terjesen et al., 2013). Nitrification, the oxidation of ammonia via nitrite to nitrate, is a common microbially mediated process in RAS biofilters that additionally remove dissolved organic matter (Hagopian and Riley, 1998; Suhr et al., 2013; Daims et al., 2015). Various biofilter materials and different types of biofilters are applied in RAS (Eding et al., 2006; Malone and Pfeiffer, 2006; Ødegaard, 2006; Summerfelt, 2006; Pfeiffer and Wills, 2011) in order to ensure optimal performance and TAN removal. Being microbial ecosystems, biological filters are vulnerable to environmental changes, which often occur in commercial aquaculture systems. Various species are successfully reared in RAS, and recently, grow out of e.g. salmon (Salmo salar) and king fish (Seriola lalandi) in land-based marine RAS have started in Denmark (Dalsgaard, 2017). Sea bream (Sparus aurata) and sea bass (Dicentrarchus labrax) are examples of RAS candidates reared in the Mediterranean region (Hochheimer and Wheaton, 1997; Eshchar et al., 2006; Bregnballe, 2015). Emergence of these new candidate species and production plans including brackish and marine environment require knowledge of how the nitrification process is affected by salinity and changes therein. Although the recent development of land-based RAS (Martins et al., 2010; Dalsgaard et al., 2013) calls for more knowledge of potential implications caused by salinity, relatively limited information is available on the effect of salinity and salinity changes on nitrification kinetics (Chen et al., 2006). Deliberate salinity increases up to 10-15 \%o during land-based Atlantic salmon smolts production or periodically fluctuations in salinity due to salt addition to treat for parasites (Aihua and Buchmann, 2001) may potentially compromise RAS operation since impaired biofilter performance may lead to deteriorated water quality (Colt, 2006; Lyssenko and Wheaton, 2006; Wolters et al., 2009; Yogev et al., 2017).

Salinity thus plays a central role in RAS design and dimensioning taking also other productionrelated factors into consideration (Wolters et al., 2009; Diaz et al., 2012; Terjesen et al., 2013). Previous studies have reported salinity effects on reaction rates for both ammonia oxidizing bacteria $(\mathrm{AOB})$ and nitrite-oxidizing bacteria (NOB) after addition of salt $(\mathrm{NaCl})$ above $5 \%$ (Sánchez et al., 2004; Timmons and Ebeling, 2010). Another study reported severe effects of salinity on NOB and nitrite oxidation removal rate and on ammonia removal to a minor degree (Aslan and Simsek, 2012). At very low salinity, $\mathrm{NaCl} \leq 3.7 \%$, only minor effects were reported whereas complete inhibition was observed at a salinity of $\mathrm{NaCl} \geq 24 \%$ (CortésLorenzo et al., 2015). Salinity changes and increases affect bacterial community and composition in RAS biofilter, and Gonzalez-Silva et al. (2016) reported ceased activity of nitrifying bacteria following a shock treatment of a $\mathrm{NaCl}$-salinity $>22 \%$. 
Previous studies have often applied synthetic salts and/or applied biofilter elements from systems without fish and have mainly investigated TAN removal (Lyssenko and Wheaton, 2006). These results can be indicative of salinity effects, but are not easily extrapolated from lab scale to commercial RAS biofilter systems (Lopato et al., 2013; Kamstra et al., 2017).

The aim of this study was to investigate the effects of abrupt salinity increase on both steps of the nitrification process in substrate limited ( $1^{\prime}$-order) and substrate u unlimited ( $0^{\prime}$-order) concentrations. All experiments were carried out using moving bed biofilter-elements obtained from a stable long term operating RAS in steady state. These elements were tested controlled conditions (constant temperature, alkalinity, filling rate, elevation speed and exposure time) and spiked with either TAN or nitrite at relevant dosages. The water used was mixed from two operating RASs, a freshwater RAS and a brackish RAS with diluted seawater (25\%) both holding rainbow trout (Oncorhynchus mykiss) with a feed loading to mimic commercial model trout farms (Jokumsen and Svendsen, 2010).

\section{Materials and Methods}

\subsection{RAS and biofilter media}

Moving bed biofilter media (RK BioElements ${ }^{\circledR}$ Neutral, RK Plast, Denmark, specific surface area $=750 \mathrm{~m}^{2} \cdot \mathrm{m}^{-3}$ ) were taken from an experimental freshwater RAS facility operated for several month in steady-state at $12-14^{\circ} \mathrm{C}$ at DTU Aqua, Hirtshals, Denmark.

The $8.5 \mathrm{~m}^{3}$ experimental RAS was composed of a rearing tank stocked with $130 \mathrm{~kg}$ rainbow trout (Oncorhynchus mykiss) fed 1000 gram feed per day and operated at a feed loading of 1 $\mathrm{kg}$ feed $/ \mathrm{m}^{-3}$ make-up water. The RAS had two $0.40 \mathrm{~m}^{3}$ fixed bed and two $0.40 \mathrm{~m}^{3}$ moving bed biofilters each filled with 200 I RK BioElements (Pedersen et al., 2015). Elements from the moving bed biofilters were used for this study and freshwater was taken from this RAS as well (Table 1). Saline water was collected from a RAS operated at $25 \%$ at DTU Aqua, Hirtshals, Denmark. The system consisted of six individual 1000-L tanks with rainbow trout (20-25 $\mathrm{kg} /$ tank) each fed 250-300 g/day. The $25 \%$ saltwater RAS facility was operated at steady state at $16^{\circ} \mathrm{C}, \mathrm{pH} 7.5-8.0$, and a feed loading of approximately $1 \mathrm{~kg}$ feed $\mathrm{m}^{-3}$.

\subsection{Experimental setup and system water mixing}

A series of independent moving bed biofilter reactors operated as batch reactors were used ensuring precise control of biofilter hydraulic conditions in each reactor (Colt, 2006). Each 6.4-L reactor was connected to a 8-W aquarium pump (Silence 1073.008, Tunze, Germany) with a 20-mm hose pipe from the reactor's top outlet to the suction part of the pump. From there, water was returned into the bottom of the reactor through a flowmeter (SK-61, Georg Fischer, Germany). The reactor set-up also included a common air pump (RESUN ${ }^{\circledR}$ LP40, China), delivering air to each reactor controlled by a flowmeter set at $0.5 \mathrm{~L} /$ minute to ensure consistent movement and aeration of the biomedia (Fig. 1). 
To obtain a given salinity for the trials, water was mixed from the two RAS. The salinity levels tested were: $0,5,10,15,25$ and $35 \%$. The inclusion of brackish system water from the marine RAS facility for each predefined salinity level was calculated as follows:

$S_{w}=\frac{R_{\% 0}}{S_{w_{\% 0}}} \times 100 \%$

Where, $S_{w}$ is the amount of brackish RAS water in $L, R_{\%}$ is the predefined required salinity level in ppt and $\mathrm{S}_{\mathrm{w} \%}$ is the salinity of water from the marine RAS facility (in this case $25 \%$ ). The percentage inclusion needed from the freshwater RAS facility was obtained by subtracting the saltwater \% in equation (1) from $100 \%$ (Table 1). For 35\%o, pure seawater was used.

\subsection{Experimental protocol}

Six 6.4-L reactors were installed in a cooling room set at $12^{\circ} \mathrm{C}$. Each experimental run included a standardized procedure, where $5 \mathrm{~L}$ of RAS water was added to each reactor. Hereafter, a volume of $2.4 \mathrm{~L}$ active bioelements were gently transferred from one of the operating moving bed biofilters to each of the six reactors. A $50-\mathrm{mL}$ syringe was used to inject additional water into the hose connecting the reactor to the pump. Water and air pump were then turned on to initiate water circulation inside the reactor. Water and airflow were set to $60 \mathrm{~L} /$ hour and $0.5 \mathrm{~L} /$ minute, respectively. The reactors were operated and acclimated for 1 hour before the first spiking to ensure that any residual TAN and nitrite in the transferred RAS water were degraded.

Four sets of spiking experiments was performed: low concentration ( $\left.1 \mathrm{mg} \cdot \mathrm{L}^{-1}\right)$ TAN or nitrite spikes and high concentration $\left(5 \mathrm{mg} \cdot \mathrm{L}^{-1}\right)$ TAN or nitrite spikes. Low concentration spikes were used to evaluate substrate (TAN or nitrite) limited removal rates (1'-order kinetics). High concentration spikes were used to evaluate substrate independent TAN and nitrite- $\mathrm{N}$ removal rates (0'-order kinetics) (Hagopian and Riley, 1998; Pedersen et al., 2015; von Ahnen et al., 2015). For analyses of TAN, nitrite and nitrate, a volume of $8 \mathrm{ml}$ was sampled from each reactor every 10 minutes and filtered using a $0.2 \mu \mathrm{m}$ sterile filter (Sartorius, Germany) and stored at $2^{\circ} \mathrm{C}$ for later analysis. Water sampling was performed over a period of 120 minutes.

In a preliminary reference experiment, six reactors were used in two consecutive trials. For both TAN and nitrite, triplicate spiking experiments were made $(N=12)$ where either $5 \mathrm{ml}$ or $25 \mathrm{ml} 1000 \mathrm{mg} \cdot \mathrm{L}^{-1} \mathrm{TAN}$ or Nitrite-N stock solutions were spiked into each reactor.

Assessment of low concentration (substrate dependent) ammonia and nitrite removal rates (1' order kinetics)

Six reactors of six different salinities $\left(0,5,10,15,25\right.$ and $35 \%$ ) at $12{ }^{\circ} \mathrm{C}$ (Fig. 2) were used. To attain data set in true triplicates, randomized serial spikes $\left(\mathrm{C}_{0}\right.$ equivalent to $1 \mathrm{mg} \cdot \mathrm{L}^{-1} \mathrm{TAN}$ or nitrite-N) were performed over six consecutive days $(N=36)$ using newly transferred 
bioelements for each trial. Water samples were collected every 10 minutes for 120 minutes to assess substrate-dependent first-order removal rates.

Assessment of high concentration (substrate independent) ammonia and nitrite removal rates (O' order kinetics)

In direct continuation of the spiking trials at low substrate levels, five-fold stronger spikes with TAN or nitrite- $\mathrm{N}$ were made to assess the substrate independent removal rates $\left(0^{\prime}\right.$ kinetics). Ninety-six $\mathrm{ml}$ of the specific salinity mixed RAS water was refilled into each reactor to compensate for the samples water and obtain a fixed volume of $5 \mathrm{~L}$ in each reactor. After one hour, each reactor was spiked with either $25 \mathrm{ml} 1000 \mathrm{mg} \mathrm{NH}-\mathrm{N} \cdot \mathrm{L}^{-1}$ or $25 \mathrm{ml} 1000 \mathrm{mg}$ $\mathrm{NO}_{2}-\mathrm{N} \cdot \mathrm{L}^{-1}$ respectively. As above, water samples were collected after $10,20,30,40,50,60$, $75,90,105,120,150,180,210,240,270$, and 300 minutes. After finishing the sampling, all reactors were emptied and refilled with new water and new biofilter elements for the next experimental run.

\subsection{Water chemistry analysis}

Samples were filtered through $0.20 \mu \mathrm{m}$ syringe filters (Filtropur $\mathrm{S} 0.20 \mu \mathrm{m}$, Sarstedt, Germany) prior to analyses of inorganic $N$ forms including total ammonia nitrogen (TAN; (DS 224, 1975) and nitrite-N (DS 223, 1991) using a DR2800 Spectrophotometer $\left(\mathrm{HACH}^{\circledR}\right.$, Germany). Nitrate-N was analysed in selected water samples using lon Chromatograph analysis (930 Compact IC Flex, Metrohm, Denmark). Water temperature, dissolved oxygen, and $\mathrm{pH}$ were measured using a $\mathrm{HQ} 40 \mathrm{~d}$ multimeter $\left(\mathrm{HACH}^{\circledR}\right.$, Germany). Alkalinity was measured as the equivalent acid titrant needed to reach $\mathrm{pH} 4.5$ using Lab X auto titration T50 (Mettler Toledo, Denmark).

\subsection{Calculations}

Substrate removal rates following spiking were calculated separately for concentration ranges where degradation was limited by substrate concentration (first order), as well as for higher concentration ranges where substrate was not limiting the degradation process (zero order) (Henze et al., 2002).

\section{First order nitrification kinetics}

Data points (all below $1.3 \mathrm{mg} / \mathrm{l}$ ) from the spiking with $5 \mathrm{ml}$ of $1000 \mathrm{mg}$ TAN/L or $1000 \mathrm{mg} \mathrm{NO} 2^{-}$ $\mathrm{N} / \mathrm{L}$ solution were used to assess the substrate-dependent removal rates for ammonia and nitrite, respectively. First-order degradation kinetics were described using least square linear regression on In-transformed substrate concentrations versus time as applied in Prehn et al.,(2012). Regressions were fitted in the form $y=a x+b$ where $y$ is the In-transformed substrate concentration in the bulk water, $x$ is the time after spiking, and $a$ (slope) and $b$ are constants. The first-order rate constant $k_{1 a}\left(m \cdot d^{-1}\right)$ was calculated from the slope of the regression line of the In-transformed data multiplied by the total water volume of the reactor 
and divided by the total surface area of the biofilter media, (von Ahnen et al., 2015). Rate constants are expressed as averages of the replicated spiking trials.

\section{Zero order nitrification kinetics}

The surface specific TAN removal (STR; $\mathrm{g} \mathrm{N} \cdot \mathrm{m}^{-2} \cdot \mathrm{d}^{-1}$ ) and the surface specific nitrite removal (SNR; g N $\cdot \mathrm{m}^{-2} \cdot \mathrm{d}^{-1}$ ) were calculated according to Kinyage and Pedersen (2016) as described in equation 2 and 3 below;

$\mathrm{STR}=\frac{S_{T A N} \times V_{w} \times 60 \mathrm{~min} \mathrm{~h}^{-1} \times 24 h \mathrm{~d}^{-1}}{A_{m} \times 1000 \mathrm{mg} \mathrm{g}^{-1}}$

Where $S_{\text {TAN }}$ is the volumetric TAN degradation rate in $\mathrm{mg} \mathrm{N} \cdot \mathrm{m}^{-3} \cdot \mathrm{min}^{-1} ; \mathrm{V}_{\mathrm{w}}$ is volume of water in the reactor in $\mathrm{m}^{3}$; and $A_{m}$ is the total surface area of the biomedia in $\mathrm{m}^{2}$. Similarly, the surface specific nitrite-nitrogen removal (SNR; $\mathrm{g} \mathrm{N} \cdot \mathrm{m}^{-2} \cdot \mathrm{d}^{-1}$ was calculated as:

$\mathrm{SNR}=\frac{S_{N} \times V_{w} \times 60 \mathrm{~min} \mathrm{~h}^{-1} \times 24 h d^{-1}}{A_{m} \times 1000 \mathrm{mg} \mathrm{g} \mathrm{g}^{-1}}$

Where $S_{N}$ is the nitrite-nitrogen degradation rate in $\mathrm{mg} \mathrm{N} \cdot \mathrm{m}^{3} \cdot \mathrm{min}$ ); $\mathrm{V}_{\mathrm{w}}$ is volume of water in the reactor in $\mathrm{m}^{3} ; \mathrm{A}_{\mathrm{m}}$ is the total surface area of the bioelements in $\mathrm{m}^{2}$.

For both TAN and nitrite- $\mathrm{N}$, only data values above $1.0 \mathrm{mg} \mathrm{N} \cdot \mathrm{l}^{-1}$ were used to assess the linear, substrate unlimited zero-order removal (von Ahnen et al., 2015).

The relative inhibition (\%) caused by salinity increases was calculated according to formula (4) below:

Relative Inhibition $=\left[\left(N_{R}-N_{S}\right) / N_{R}\right]^{*} 100 \%$

Where $N_{R}$ and $N_{S}$ are removal at the reference reactor and reactors with the respective salinity levels, expressed in $\mathrm{m} \cdot \mathrm{d}^{-1}$ for $k_{1 a}$ and $\mathrm{N} \cdot \mathrm{m}^{-2} \cdot \mathrm{d}^{-1}$ for STR and SNR.

\subsection{Statistics}

Differences between treatments with different salinity levels for TAN and nitrite-nitrogen removal for first and zero-order nitrification kinetics were tested using one-way ANOVA followed by Tukey's post-hoc test. Experimental data were obtained from a Completely Randomized Design Experiment for each salinity level in triplicate. To test for significant differences between salinity levels, a statistical level of significance of $p<0.05$ was applied for all analysis using GraphPad Prism 5 software. The relative inhibition of abrupt salinity increase on $k_{1 a}$, STR, and SNR was analysed using Sigma-Stat ${ }^{\circledR}$ software. 


\section{Results}

\subsection{First order nitrification kinetics}

\section{Ammonia removal}

The freshwater (FW)-reference degradation, measured 1 day prior to the main experiment, showed a reduction in ammonia concentration from the initial $1 \mathrm{mg} \mathrm{TAN} \cdot \mathrm{L}^{-1}$ to $0 \mathrm{mg} \mathrm{TAN} \cdot \mathrm{I}^{-1}$ in 90 minutes. A similar reduction in ammonium concentration was observed in the reactors operated at $0 \%$ and $5 \%$ in all experimental runs (Fig. 3A). At 10\%, TAN removal was reduced and at $15 \%$ almost no TAN degradation occurred. At $25 \%$ ond $35 \%$, no reduction in TAN concentration was observed (Fig. 3A).

While the first order rate constant $k_{1 a}$ was similar $\left(0.22 \mathrm{~m} \cdot \mathrm{d}^{-1}\right)$ for the FW-reference and $0 \%$, a minor decrease was observed at $5 \%\left(0.17 \mathrm{~m} \cdot \mathrm{d}^{-1}\right)$, and a significant decrease was observed with further increase in salinity. At $10 \%$, $k_{1 a}$ was $0.04 \mathrm{~m} \cdot \mathrm{d}^{-1}$ and $15 \%$ only $0.01 \mathrm{~m} \cdot \mathrm{d}^{-1}$. At higher salinities the rate constant was $0 \mathrm{~m} \cdot \mathrm{d}^{-1}$ (Table 2).

\section{Nitrite removal}

Similar results were obtained for the first-order removal of nitrite-nitrogen. Fig. 3B shows a pronounced reduction in the nitrite-nitrogen concentration over time for the FW-reference, as well as for reactors operated at $0 \%$ and $5 \%$. At $10 \%$ o nitrite turnover was impaired by about half, and at $15 \%$ was almost totally hampered. No nitrite removal was observed at the higher salinity levels at 25 and 35\%o.

As for TAN removal, reactors operated at $0 \%$ and $5 \%$ o had similar nitrite removal rate constants $\left(\mathrm{k}_{1 \mathrm{a}}\right)$ of $0.24 \mathrm{~m} \cdot \mathrm{d}^{-1}$ and $0.25 \mathrm{~m} \cdot \mathrm{d}^{-1}$, respectively, in line with the $\mathrm{FW}$ reference of 0.23 $m \cdot d^{-1}$. With increasing salinity, a drastic drop in $k_{1 a}$ values was observed. At $10 \%$ o $k_{1 a}$ was 0.05 $\mathrm{m} \cdot \mathrm{d}^{-1}$ and at $15 \%$ o $0.01 \mathrm{~m} \cdot \mathrm{d}^{-1}$ (Table 2). At $25 \%$ ond $35 \%$ o no nitrite was removed and $\mathrm{k}_{1 \mathrm{a}}$ consequently was $0.00 \mathrm{~m} \cdot \mathrm{d}^{-1}$.

\subsection{Zero-order nitrification kinetics}

\section{Ammonia removal rates}

At high substrate loading, the initial TAN concentration at the second spike varied from one salinity level to the other as incomplete nitrification in reactors operated at higher salinities in the previous spike lead to residual TAN. In this case, a steep decline in TAN concentration was observed in reactors operated in freshwater or in system water mixture with low salinity levels (up to 5\%o), while no reduction in TAN concentration was observed when bioelements from a freshwater RAS biofilter were subjected to water with a salinity of $25 \%$ and above (Fig. 4A).

As a result, the surface specific TAN removal (STR) was higher at lower salinities; 0.1 and 0.09 $\mathrm{g} \mathrm{TAN} \cdot \mathrm{m}^{-2} \cdot \mathrm{d}^{-1}$ for the FW reference and $5 \%$ salinity, respectively. A significant reduction in 
STR was observed with increasing salinity. At $10 \%$ o STR was only $0.01 \mathrm{~g} \mathrm{TAN} \cdot \mathrm{m}^{-2} \cdot \mathrm{d}^{-1}$ (Table 2 ) and for all salinities above $10 \%$, no TAN was removed $\left(\mathrm{STR}=0 \mathrm{~g} \mathrm{TAN} \cdot \mathrm{m}^{-2} \cdot \mathrm{d}^{-1}\right)$.

\section{Nitrite removal rate}

Salinity increase had a similar effect on nitrite-nitrogen removal at high loading. At low to moderate salinities nitrite-nitrogen concentration declined fast, while no reduction was observed at $25 \%$ and above (Fig. 4B). Like STR, SNR was hampered by increasing salinity. For both processes, almost total inhibition was observed at $15 \%$ and upwards (Table 2 ).

The effects of abrupt salinity changes on the relative inhibition of the two nitrification processes, both at low and high substrate levels are depicted in Fig. 5. Showing a common and fairly narrow transition zone from 10 to $15 \%$ o salinity.

\section{Discussion}

\subsection{Ammonia removal rates}

Removal rates for TAN were measured at low and high substrate loading to assess 0 '-order and 1 '-order kinetics at different salinities following abrupt salinity increases. The results comply with the general experience that biofilter performance are unaffected by minor changes in salinity, for example related to addition $\mathrm{NaCl}$ to treat for parasites (Matthews, 2005; Iørgensen, 2017). However, when exceeding 10\%o salinity, reductions occur almost exponentially.

The TAN oxidation process in the zero-order concentration area was almost unaffected at $5 \%$ while $60 \%$ inhibition was observed at $10 \%$. Almost complete inhibition (95\%) occurred at $15 \%$ and when subjected to salinities of $25 \%$ and upwards, $100 \%$ inhibition was observed. Gonzalez-Silva et al., (2016) reported $97 \%$ inhibition in a bath experiment when a freshwater biofilter was subjected to highly saline water (Moussa et al. (2006) reported 95\% inhibition of AOB's when $40 \mathrm{~g} \mathrm{NaCl} / \mathrm{L}$ synthetic salt was added. Our results in the zero-order concentration area is also in line with those of previous studies reporting insignificant salinity effects on freshwater biofilter nitrification of salinities $\leq 10 \%$ (Nijhof and Bovendeur, 1990).

The effect of salinity on TAN removal rates in the first-order concentration area has rarely been reported in previous studies. In this study, TAN removal rate constants $\left(k_{1 a}\right)$ of $0.22 \mathrm{~m} \cdot \mathrm{d}^{-}$ ${ }^{1}$ were found in freshwater (the reference and $0 \%$ o treatment) while removal rates were affected ( $23 \%$ inhibition) even at low salinity (5\%). At 10\%o and 15\%o salinity, 82 and $95 \%$ inhibition was observed, respectively. This result suggests that when AOBs are limited by substrate availability, they become even more sensitive to abrupt changes in salinity, Table 2. 


\subsection{Nitrite removal rates}

Nitrite build-up in RAS can have lethal effects on fish (Svobodova et al., 2005). The nitrification process in a biofilter is complete only if the second step, nitrite to nitrate conversion, is successful (Lekang, 2013). Similarly to ammonia removal rates a significant salinity effects on nitrite removal was observed (Table 2). For zero and $1^{\prime}$ order kinetics, SNR and $k_{1 a}$ of $0.12 \mathrm{~g}$ $\mathrm{N} \cdot \mathrm{m}^{-2} \cdot \mathrm{d}^{-1}$ and $0.23 / 0.24 \mathrm{~m} \cdot \mathrm{d}^{-1}$, respectively, were observed in this study for reactors operated with system freshwater. A similar range of SNR; $0.10 \mathrm{~g} \mathrm{~N} \cdot \mathrm{m}^{-2} \cdot \mathrm{d}^{-1}$ and $0.19 \mathrm{~m} \cdot \mathrm{d}^{-1}$ were reported by von Ahnen et al.,(2015). A subsequent increase in salinity affected nitrite conversion efficiency with inhibition reaching $100 \%$ when freshwater bioelements were abruptly subjected to salinity levels of $25 \%$ and above. This immediate inhibition in NOB function may primarily be related to homeostatic disturbances including cell shrinkage due to hyperosmotic conditions(Cortés-Lorenzo et al., 2015). This will cause an acute effect on all bacteria, and over time lead to or shift in microbial composition (Moussa et al., 2006; Rud et al., 2017).

\subsection{Nitrate concentration}

A complete nitrification process results in an increase in the nitrate concentration equivalent to the ammonia and nitrite addition by the initial spike solution. In this study, net increases in nitrate concentration of 1 and $5 \mathrm{mg} \mathrm{N} / \mathrm{L}$ were observed for $1^{\prime}$ and $0^{\prime}$-order spiking, respectively, in reactors operated at $0 \%$, demonstrating complete TAN-conversion. A similar experiment showed a net increase of $7 \mathrm{mg} \mathrm{N} / \mathrm{L}$ nitrate for complete nitrification when spiked with $7 \mathrm{mg} \mathrm{N} / \mathrm{L}$ initial ammonia concentration (Nijhof and Bovendeur, 1990). In our study, an increase in salinity resulted in incomplete nitrification and concomitantly a reduced increase in nitrate concentration in reactors operated at higher salinity levels (Table 3 and 4 in Appendix).

The finding in this study stresses the effect of N-loading when determining STR and SNR at higher loadings (Pedersen et al., 2012), and TAN and nitrite removal rate constants at low loadings (Table 2); yet the relative salinity effects remained similar in all tests (Fig. 5). Reactors operated in freshwater showed no inhibition, while complete inhibition was observed in reactors operated with either brackish RAS system water at $25 \%$, or full strength seawater at $35 \%$.

\subsection{Salinity effect on microbial community}

Previous studies have reported diversity differences for $A O B$ and NOB microbial communities in freshwater and marine RAS biofilters. Salinity changes cause pronounced changes in bacterial populations and activities (Ludzack and Noran, 1965). Lee et al. (2016) and Huang et al. (2018) reported a diverse nitrifying bacteria community in seawater RAS facilities at salinity levels between 20 and $35 \%$. Increase in salinity might affect cell volume regulation in freshwater cells or lead to shrinkage affecting basal metabolic processes (Lefebvre and Molleta, 2006; He et al., 2017). Salt-induced environmental change affects nitrifying bacteria, as relative poor nitrification efficiency is reported in freshwater systems operated at salinity 
levels of $22 \%$ and above due to poor adaptation of AOBs at increased salinity (Bakke et al., 2017). Decreases in STR might be due to osmotic changes affecting the functions of operational taxonomic units among the AOB microbiota on the MBB biofilm (Gonzalez-Silva et al., 2016).

The mechanisms and extent to which microbial communities can potentially adapt to different salinities are not fully known but practical experiences indicate that gradual and even abrupt changes in salinity can be done with less dramatic effects on nitrification once the biofilters have experienced such rises and falls in salinity several times. Future aquaculture saltwater nitrification studies should include, but not be limited to i) investigate mode of salinity change over prolonged periods of time (Navada, 2018) ii) test of combined low temperature and salinity effects on nitrification, iii) potentials of bio-augmentation or seeding new biofilter elements with colonized biofilter elements and iv) document and compare STR and SNR rates of biofilter from commercial brackish and saltwater RAS.

\section{Conclusion}

The results of this study demonstrated that abrupt changes in salinity have significant effect on both steps of the nitrification process and that the effect is comparable in first- and zeroorder concentrations. Ammonia and nitrite removal rates were reduced by some $25 \%$ at $10 \%$ o salinity and by some $93 \%$ at $15 \%$ salinity. This highlights the point that awareness is needed if RAS salinities are rapidly increased above $10 \%$. A complete inhibition of ammonia as well as nitrite removal, both in $1^{\prime}$ - and $0^{\prime}$-order kinetics, were observed when biofilter elements from freshwater RAS were acutely operated in seawater from a marine RAS at $25 \%$. As brackish and saltwater RAS develop very rapidly, there is an urgent need for more research into understanding and optimizing biofiltration at different salinities.

\section{Acknowledgement}

This work was part of the Building Stronger Universities BSU II Project funded by DANIDA (Danish Foreign Aid) and co-administered by Sokoine University of Agriculture, Tanzania, and the Technical University of Denmark, DTU Aqua. The authors would like to extend their appreciation to Prof. Sebastian Wilson Chenyambuga, Dr. Daniel Mushi, Dr. Kirsten Thomsen and Mrs Lene Zohnesen for coordination of the pilot projects that lead to this work. We also give special thanks to the laboratory technicians: Ulla Sproegel, Dorte Frandsen, Brian Møller, and Melissa Lyng for their support in the lab and Ole Larsen, Rasmus Nielsen and Gunnar Vestergaard for their tireless technical support. 


\section{Reference}

Aihua, B.L., Buchmann, K., 2001. Temperature- and salinity-dependent development of a Nordic strain of Ichthyophthirius multi ${ }^{\circledR}$ liis from rainbow trout. J. Appl. Ichthyol. 17, 273-276.

Aslan, S., Simsek, E., 2012. Influence of salinity on partial nitrification in a submerged biofilter. Bioresour. Technol. 118, 24-29.

Bakke, I., Am, A.L., Kolarevic, J., Ytrestoyl, T., Vadstein, O., Attramadal, K.J.K., Terjesen, B.F., 2017. Microbial community dynamics in semi-commercial RAS for production of Atlantic salmon post-smolts at different salinities. Aquac. Eng. 78, 42-49.

Bregnballe, J., 2015. A Guide to Recirculation Aquaculture, FAO and Eurofish Report.

Chen, S., Ling, J., Blancheton, J.P., 2006. Nitrification kinetics of biofilm as affected by water quality factors. Aquac. Eng. 34, 179-197.

Colt, J., 2006. Water quality requirements for reuse systems. Aquac. Eng. 34, 143-156.

Colt, J., Lamoureux, J., Patterson, R., Rogers, G., 2006. Reporting standards for biofilter performance studies. Aquac. Eng. 34, 377-388.

Cortés-Lorenzo, C., Rodríguez-Díaz, M., Sipkema, D., Juárez-Jiménez, B., Rodelas, B., Smidt, H., González-López, J., 2015. Effect of salinity on nitrification efficiency and structure of ammonia-oxidizing bacterial communities in a submerged fixed bed bioreactor. Chem. Eng. J. 266, 233-240.

Daims, H., Lebedeva, E. V., Pjevac, P., Han, P., Herbold, C., Albertsen, M., Jehmlich, N., Palatinszky, M., Vierheilig, J., Bulaev, A., Kirkegaard, R.H., Von Bergen, M., Rattei, T., Bendinger, B., Nielsen, P.H., Wagner, M., 2015. Complete nitrification by Nitrospira bacteria. Nature 528, 504-509.

Dalsgaard, J., 2017. 4th NordicRAS Workshop on Recirculating Aquaculture Systems, in: Dalsgaard, J. (Ed.), DTU Aqua Report No. 321-2017. Aalborg, Denmark.

Dalsgaard, J., Lund, I., Thorarinsdottir, R., Drengstig, A., Arvonen, K., Pedersen, P.B., 2013. Farming different species in RAS in Nordic countries: Current status and future perspectives. Aquac. Eng. 53, 2-13.

Diaz, V., Ibanez, R., Gomez, P., Urtiaga, A.M., Ortiz, I., 2012. Kinetics of nitrogen compounds in a commercial marine recirculating aquaculture system. Aquac. Eng. 50, 20-27.

DS 223, 1991. Water Analysis - Determination of the Sum of Nitrite- and Nitrate-Nitrogen. Danish Standards Foundation, Charlottenlund, Denmark.

DS 224, 1975. Water Analysis - Determination of Ammonia-Nitrogen. DanishStandards Foundation, Charlottenlund, Denmark.

Eding, E.H., Kamstra, A., Verreth, J.A.J., Huisman, E.A., Klapwijk, A., 2006. Design and operation of nitrifying trickling filters in recirculating aquaculture: A review. Aquac. Eng. 34, 234-260. 
Eshchar, M., Lahav, O., Mozes, N., Peduel, A., Ron, B., 2006. Intensive fish culture at high ammonium and low pH. Aquaculture 255, 301-313.

Gonzalez-Silva, B.M., Jonassen, K.R., Bakke, I., Østgaard, K., Vadstein, O., 2016. Nitrification at different salinities: Biofilm community composition and physiological plasticity. Water Res. $95,48-58$.

Hagopian, D.S., Riley, J.G., 1998. A closer look at the bacteriology of nitrification. Aquac. Eng. $18,223-244$.

He, H., Chen, Y., Li, X., Cheng, Y., Yang, C., Zeng, G., 2017. Influence of salinity on microorganisms in activated sludge processes : A review. Int. Biodeterior. Biodegradation $119,520-527$.

Henze, M., Harremoes, P., la Cour Jansen, J., Arvin, E., 2002. Wastewater Treatment: Biological and Chemical Processes, 3rd ed. Springer Verlag, Berlin and Heidelberg.

Hochheimer, J.N., Wheaton, F.W., 1997. Intensive culture of striped bass, In: Striped Bass and Other Morone Culture. Elsevier Masson SAS, pp. 127-168.

Huang, Z., Jiang, Y., Song, X., Hallerman, E., Peng, L., Dong, D., Ma, T., 2018. Ammonia oxidizing bacteria and archaea within biofilters of a commercial recirculating marine aquaculture system. AMB Express 8, 1-12.

Jokumsen, A., Svendsen, L.M., 2010. Farming of freshwater rainbow trout in Denmark. DTU Aqua Reports 219, 1-47.

Jørgensen, L.V.G., 2017. The fish parasite Ichthyophthirius multifiliis - Host immunology, vaccines and novel treatments. Fish Shellfish Immunol. doi:10.1016/j.fsi.2017.06.044

Kamstra, A., Blom, E., Terjesen, B.F., 2017. Mixing and scale affect moving bed biofilm reactor (MBBR) performance. Aquac. Eng. 78, 9-17.

Kinyage, J.P.H., Pedersen, L., 2016. Impact of temperature on ammonium and nitrite removal rates in RAS moving bed biofilters. Aquac. Eng. 75, 51-55.

Lee, D., Lee, J., Kim, Y., Myeong, J., Kim, K., 2016. Uncultured bacterial diversity in a seawater recirculating aquaculture system revealed by $16 \mathrm{~S}$ rRNA gene amplicon sequencing. J. Microbiol. 54, 296-304.

Lekang, O.I., 2013. Aquaculture Engineering, Second. ed, Wiley \& Sons, Ltd., New York.

Lopato, L., Röttgers, N., Binning, P.J., Arvin, E., 2013. Heterogeneous nitrification in a full-scale rapid sand filter treating groundwater. J. Environ. Eng. 139, 375-384.

Ludzack, A.F.J., Noran, D.K., 1965. Tolerance of high salinities by conventional wastewater treatment processes. Water Pollut. Control Fed. 37, 1404-1416.

Lyssenko, C., Wheaton, F., 2006. Impact of positive ramp short-term operating disturbances on ammonia removal by trickling and submerged-upflow biofilters for intensive recirculating 
aquaculture. Aquac. Eng. 35, 26-37.

Malone, R.F., Pfeiffer, T.J., 2006. Rating fixed film nitrifying biofilters used in recirculating aquaculture systems. Aquac. Eng. 34, 389-402.

Martins, C.I.M., Eding, E.H., Verdegem, M.C.., Heinsbroek, L.T.., Schneider, O., Blancheton, J.P., Roque d'Orbcastel, E., Verreth, J.A.J., 2010. New developments in recirculating aquaculture systems in Europe: A perspective on environmental sustainability. Aquac. Eng. 43, 83-93.

Matthews, R.A., 2005. Ichthyophthirius multifiliis Fouquet and Ichthyophthiriosis in freshwater teleosts, in: ADVANCES IN PARASITOLOGY. pp. 160-241. Moussa, M.S., Sumanasekera, D.U., Ibrahim, S.H., Lubberding, H.J., Hooijmans, C.M., Gijzen, H.J., Van Loosdrecht, M.C.M., 2006. Long term effects of salt on activity, population structure and floc characteristics in enriched bacterial cultures of nitrifiers. Water Res. 40, 1377-1388.

Navada, S., 2018. Effect of change in water salinity on nitrification in MBBR.,Preseantation at: 5th Conference on recirculating aquaculture Sunndalsøra 23rd -24th October 2018.

Nijhof, M., Bovendeur, J., 1990. Fixed film nitrification characteristics in sea-water recirculation fish culture systems. Aquaculture 87, 133-143.

$\varnothing$ degaard, H., 2006. Innovations in wastewater treatment: The moving bed biofilm process. Water Sci. Technol. 53, 17-33.

Pedersen, L.-F., Oosterveld, R., Pedersen, P.B., 2015. Nitrification performance and robustness of fixed and moving bed biofilters having identical carrier elements. Aquac. Eng. 65, 37-45.

Pedersen, L.-F., Suhr, K.I., Dalsgaard, J., Pedersen, P.B., Arvin, E., 2012. Effects of feed loading on nitrogen balances and fish performance in replicated recirculating aquaculture systems. Aquaculture 338-341, 237-245.

Pedersen, P.B., von Ahnen, M., Fernandes, P., Naas, C., Pedersen, L.F., Dalsgaard, J., 2017. Particle surface area and bacterial activity in recirculating aquaculture systems. Aquac. Eng. 78, 18-23.

Pfeiffer, T.J., Wills, P.S., 2011. Evaluation of three types of structured floating plastic media in moving bed biofilters for total ammonia nitrogen removal in a low salinity hatchery recirculating aquaculture system. Aquac. Eng. 45, 51-59.

Prehn, J., Waul, C.K., Pedersen, L.-F., Arvin, E., 2012. Impact of water boundary layer diffusion on the nitrification rate of submerged biofilter elements from a recirculating aquaculture system. Water Res. 46, 3516-24.

Rud, I., Kolarevic, J., Buran, A., Berget, I., Calabrese, S., 2017. Deep-sequencing of the bacterial microbiota in commercial-scale recirculating and semi-closed aquaculture systems for Atlantic salmon post-smolt production. Aquac. Eng. 78, 50-62.

Rusten, B., Eikebrokk, B., Ulgenes, Y., Lygren, E., 2006. Design and operations of the Kaldnes moving bed biofilm reactors. Aquac. Eng. 34, 322-331. 
Sánchez, O., Aspé, E., Martí, M.C., Roeckel, M., 2004. The effect of sodium of the Chloride Nitrifying on the on the two-step kineticsof the nitrifying process. Water Environ. Res. 76, 73-80.

Suhr, K.I., Pedersen, P.B., Arvin, E., 2013. End-of-pipe denitrification using RAS effluent waste streams: Effect of $\mathrm{C} / \mathrm{N}$-ratio and hydraulic retention time. Aquac. Eng. 53, 57-64.

Summerfelt, S., 2006. Design and management of conventional fluidized-sand biofilters. Aquac. Eng. 34, 275-302.

Svobodova, Z., Machova, J., Poleszczuk, G., Hůda, J., Hamáčková, J., Kroupova, H., 2005. Nitrite poisoning of fish in aquaculture facilities with water-recirculating systems. Acta Vet. Brno 74, 129-137.

Terjesen, B.F., Summerfelt, S.T., Nerland, S., Ulgenes, Y., Fjæra, S.O., Megård Reiten, B.K., Selset, R., Kolarevic, J., Brunsvik, P., Bæverfjord, G., Takle, H., Kittelsen, A.H., Åsgård, T., 2013. Design, dimensioning, and performance of a research facility for studies on the requirements of fish in RAS environments. Aquac. Eng. 54, 49-63.

Timmons, M.B., Ebeling, J.M., 2010. Recirculating Aquaculture, Second ed. Cayuga AQUA VENTURES, New York.

von Ahnen, M., Pedersen, L., Pedersen, P.B., Dalsgaard, J., 2015. Degradation of urea, ammonia and nitrite in moving bed biofilters operated at different feed loadings. Aquac. Eng. 69, 5059.

Wolters, W., Masters, A., Vinci, B., Summerfelt, S., 2009. Design, loading, and water quality in recirculating systems for Atlantic salmon (Salmo salar) at the USDA ARS National Cold Water Marine Aquaculture Center (Franklin, Maine). Aquac. Eng. 41, 60-70.

Yogev, U., Sowers, K.R., Mozes, N., Gross, A., 2017. Nitrogen and carbon balance in a novel near-zero water exchange saline recirculating aquaculture system. Aquaculture 467, 118126. 


\section{Figures}

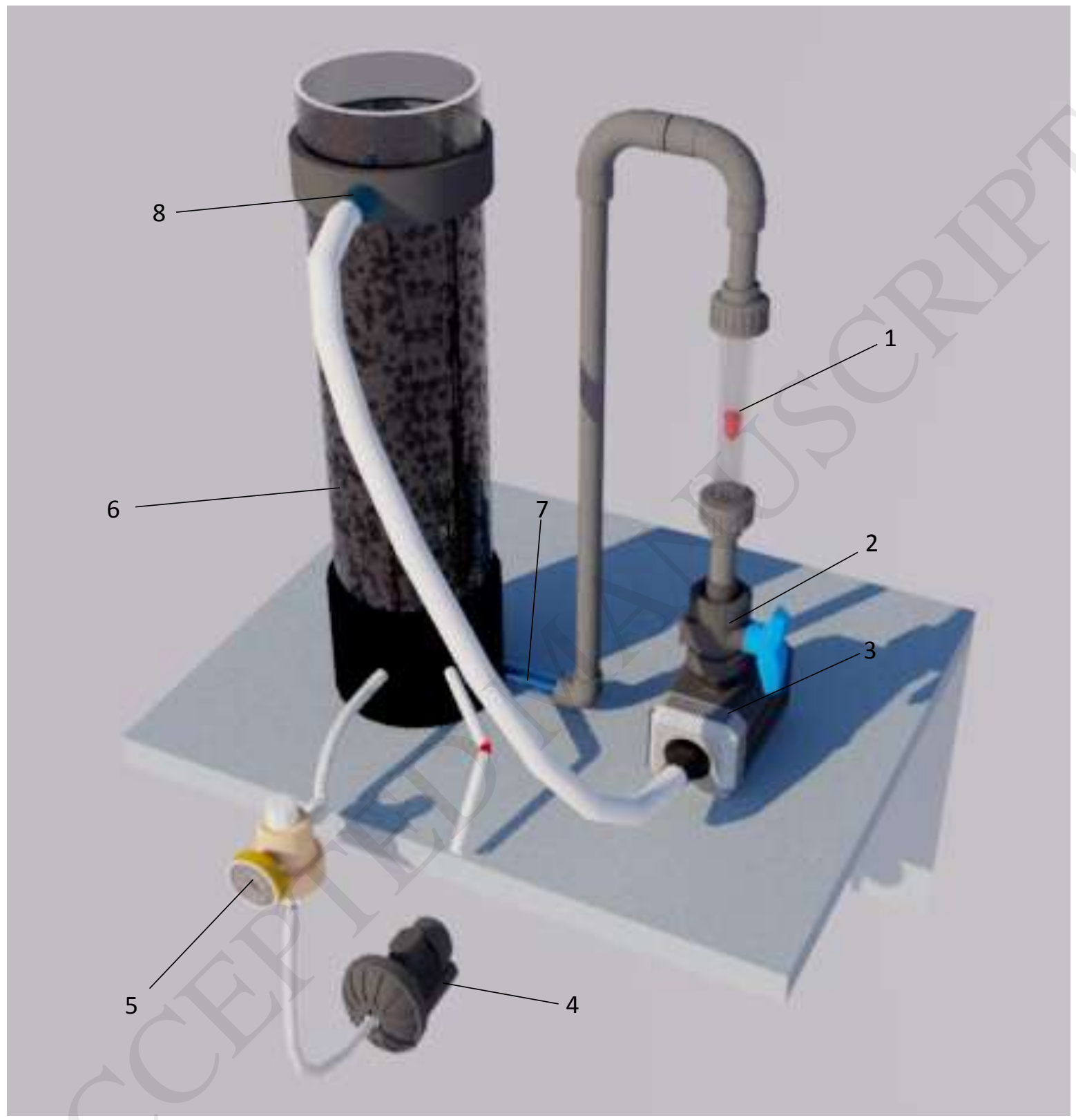

Fig. 1: A sketch of the batch reactor system setup for the nitrification experiment at different salinity levels. 1, Water flowmeter; 2, Ball valve; 3, Water pump; 4, Air pump; 5, Air flowmeter; 6 , Reactor with biofilter media; 7, reactor's inlet and 8, reactor's outlet. 


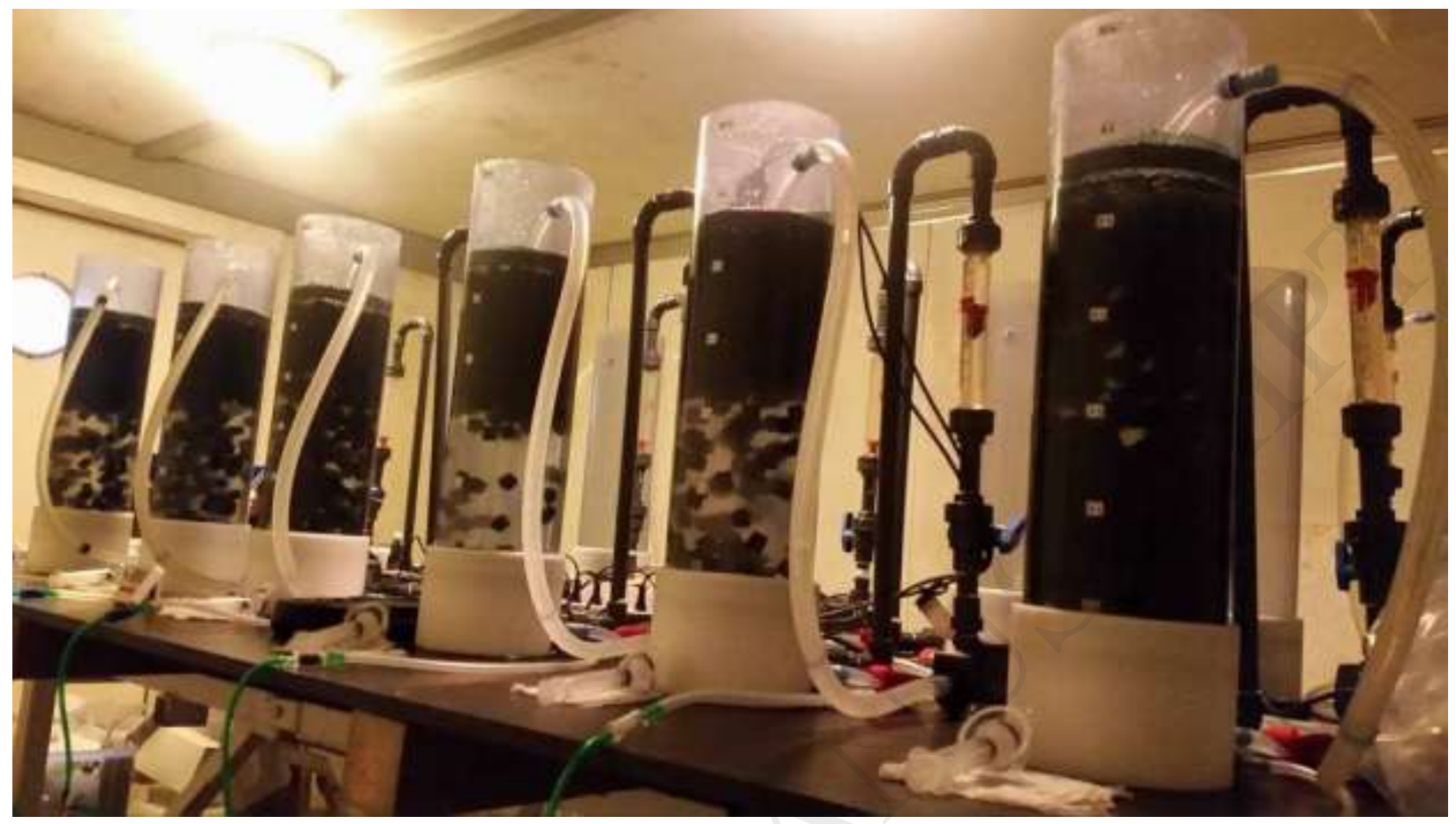

Fig. 2: Photo of randomized reactors during the experiment with media and mixture of system water at different salinity levels, from right; $0,25,35,5,10$ and $15 \%$. 

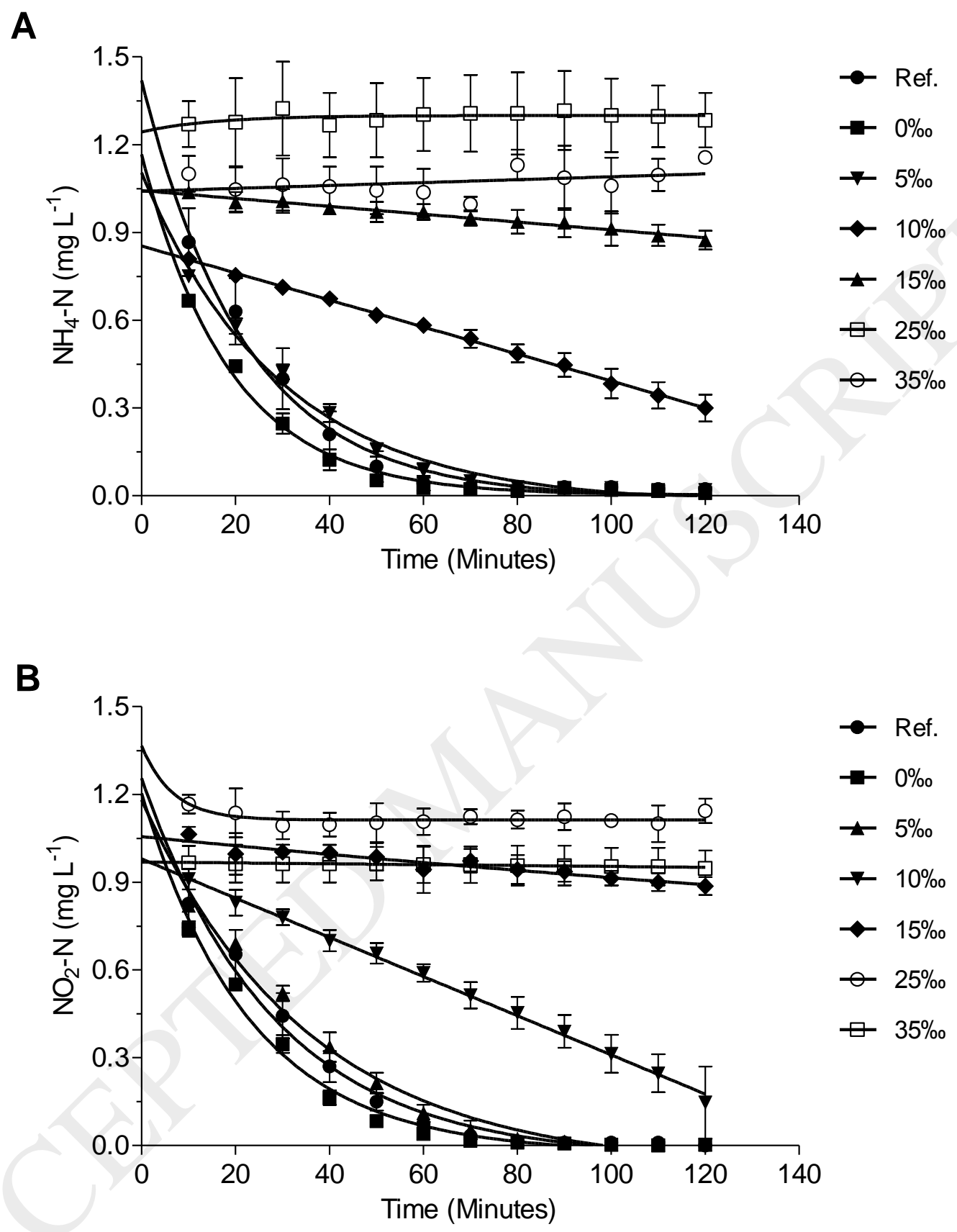

Fig. 3: Total ammonia-nitrogen (TAN) concentration (A) and nitrite-nitrogen concentration (B) observed in reactors with different salinities after spiking with $5 \mathrm{ml}$ of $1000 \mathrm{mg}$ TAN/L and $5 \mathrm{ml}$ of $1000 \mathrm{mg} \mathrm{NO}_{2}-\mathrm{N}^{-} / \mathrm{L}$ solution, respectively (data = mean $\pm \mathrm{SD}, \mathrm{n}=3$ ). 


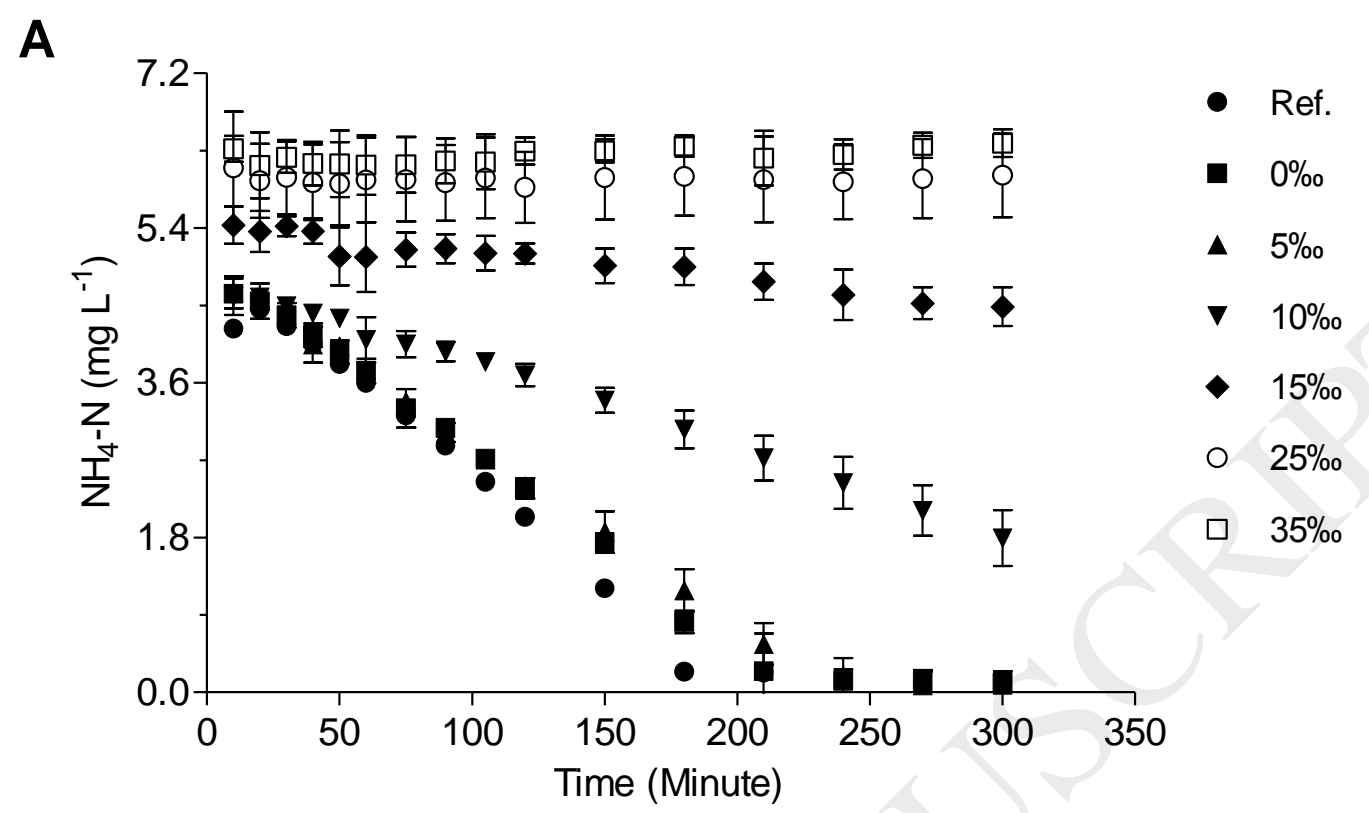

B

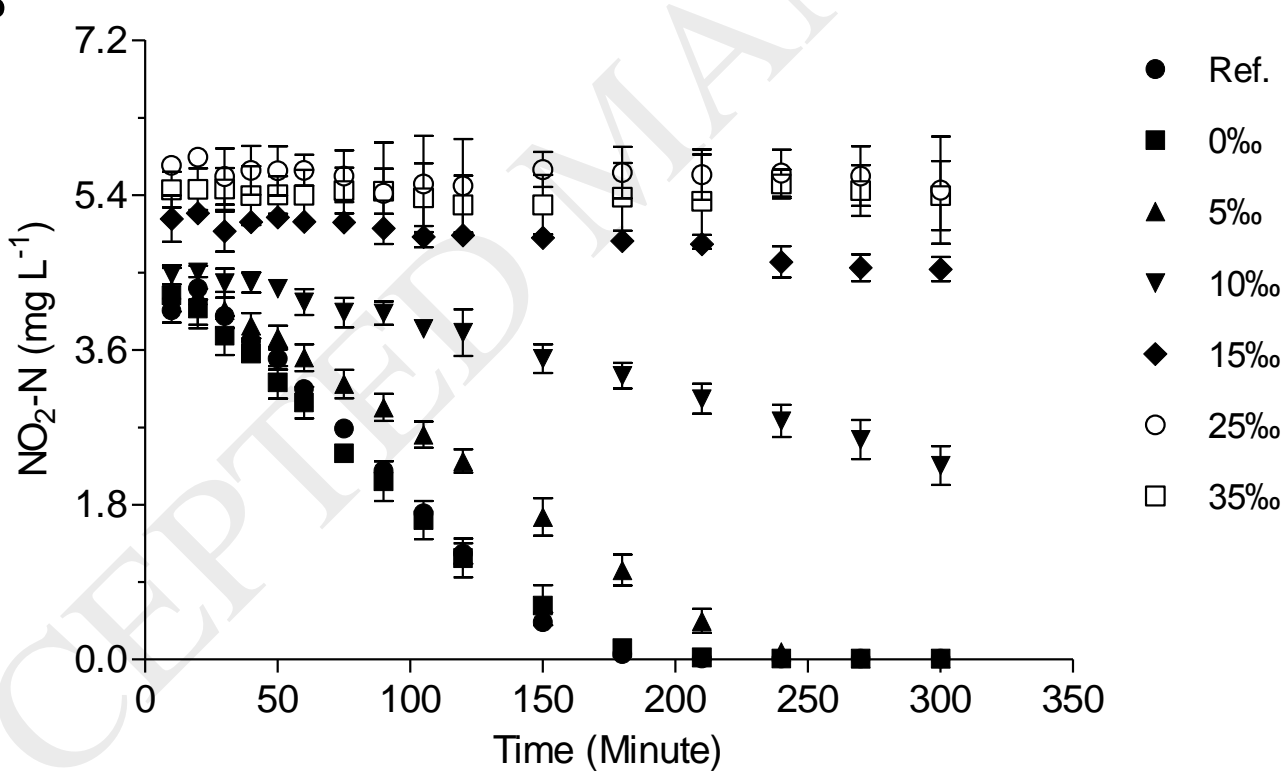

Fig. 4: Total ammonia-nitrogen (TAN) concentration (A) and nitrite-nitrogen concentration (B) observed in reactors with different salinities after spiking with $25 \mathrm{ml}$ of $1000 \mathrm{mg}$ TAN/L and 25 $\mathrm{ml}$ of $1000 \mathrm{mg} \mathrm{NO}{ }_{2}-\mathrm{N}^{-} / \mathrm{L}$ solution, respectively (data = mean $\pm S D, n=3$ ). 


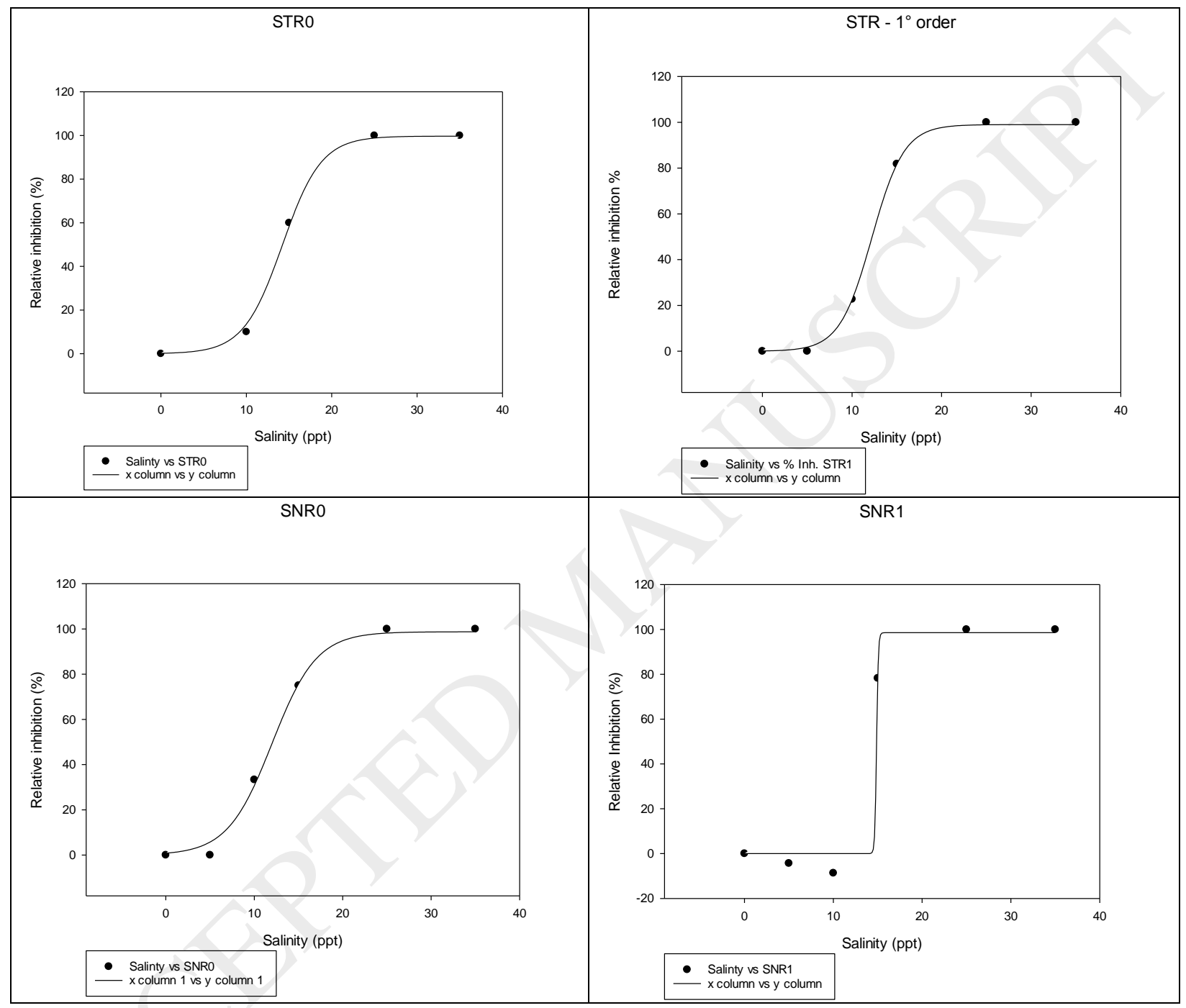

Fig. 5. Relative Inhibition (\%) of salinity on A) Surface specific TAN removal rate (STR), B) Ammonia removal rate constant $k_{1 a}(S T R$ 1), C) Surface specific nitrite removal rate (SNR) and D) Nitrite removal rate constant $\mathrm{k}_{1 \mathrm{a}}(\mathrm{SNR} 1)$. Data $=$ mean $(n=3)$ at $\mathrm{P}<0.0001, \mathrm{R}^{2}=0.9954$. 


\section{Tables}

Table 1: The percentage inclusion of system marine and freshwater RAS at different predefined salinity levels. Tap ocean water was used for full strength seawater (35\%o).

\begin{tabular}{cccc}
\hline Salinity level & \% System brackish RAS & \% System freshwater RAS & Seawater \\
\hline Ref. & - & 100 & - \\
\hline 0 & - & 100.0 & - \\
5 & 20.0 & 80.0 & - \\
10 & 40.0 & 60.0 & - \\
15 & 60.0 & 40.0 & - \\
25 & 100.0 & - & - \\
35 & - & - & 100 \\
\hline
\end{tabular}


Table 2: First- and zero-order removal rate constants, $k_{1 a}\left(\right.$ in $\left.\mathrm{m} \cdot \mathrm{d}^{-1}\right)$ and $k_{0 a}$ (in $\mathrm{g} \mathrm{N} \cdot \mathrm{m}^{-2} \cdot \mathrm{d}^{-1}$ ), respectively, for TAN and Nitrite-N oxidation in fresh water bioelements exposed to different salinities (mean $\pm S D, n=3$ ). Different superscripts within a column represent a significant difference between different salinity levels calculated at $\alpha=95 \%(P \leq 0.05)$.

\section{Error! Not a valid link.}

\section{Appendix}

Appendix Table 1: Nitrate-nitrogen concentration in the reactor at the beginning and end of sampling following a $5 \mathrm{ml} 1000 \mathrm{TAN} / \mathrm{L}$ solution addition.

Error! Not a valid link.

Appendix Table 2: Nitrate-nitrogen concentration in the reactor at the beginning and end of sampling of a 25-ml $1000 \mathrm{mg}$ TAN/L or $1000 \mathrm{mg}$ NO2-N/L respectively.

Error! Not a valid link. 
Table 2: First- and zero-order removal rate constants, $k_{1 a}\left(\right.$ in $\left.\mathrm{m} \cdot \mathrm{d}^{-1}\right)$ and $k_{0 a}$ (in $\mathrm{g} \mathrm{N} \cdot \mathrm{m}^{-2} \cdot \mathrm{d}^{-1}$ ), respectively, for TAN and Nitrite-N oxidation in fresh water bioelements exposed to different salinities (mean $\pm S D, n=3$ ). Different superscripts within a column represent a significant difference between different salinity levels calculated at $\alpha=95 \%(P \leq 0.05)$.

\begin{tabular}{|c|c|c|c|c|}
\hline \multirow{2}{*}{$\begin{array}{l}\text { Salinity level } \\
\text { (\%o) }\end{array}$} & \multicolumn{2}{|c|}{$\begin{array}{l}\text { First order rate constants, } k_{1 a} \\
\qquad\left(\mathrm{~m}^{\mathrm{d}} \mathrm{d}^{-1}\right)\end{array}$} & \multicolumn{2}{|c|}{$\begin{array}{l}\text { Zero order rate constants, k0a } \\
\qquad\left(\mathrm{g} \mathrm{N} \cdot \mathrm{m}^{-2} \cdot \mathrm{d}^{-1}\right)\end{array}$} \\
\hline & TAN & $\mathrm{NO}_{2}-\mathrm{N}$ & TAN & $\mathrm{NO}_{2}-\mathrm{N}$ \\
\hline Ref. & $0.22 \pm 0.053^{a}$ & $0.23 \pm 0.120^{a}$ & $0.10 \pm 0.002^{a}$ & $0.12 \pm 0.003^{a}$ \\
\hline 0 & $0.22 \pm 0.038^{a}$ & $0.24 \pm 0.016^{a}$ & $0.09 \pm 0.003^{b}$ & $0.12 \pm 0.009^{a}$ \\
\hline 5 & $0.17 \pm 0.027^{a}$ & $0.25 \pm 0.023^{a}$ & $0.09 \pm 0.005^{b}$ & $0.08 \pm 0.006^{b}$ \\
\hline 10 & $0.04 \pm 0.006^{b}$ & $0.05 \pm 0.012^{b}$ & $0.04 \pm 0.004^{c}$ & $0.03 \pm 0.003^{c}$ \\
\hline 15 & $0.01 \pm 0.002^{b}$ & $0.01 \pm 0.002^{c}$ & $0.01 \pm 0.003^{d}$ & $0.01 \pm 0.002^{d}$ \\
\hline 25 & $0.00 \pm 0.001^{b}$ & $0.00 \pm 0.001^{c}$ & $0.00 \pm 0.002^{e}$ & $0.00 \pm 0.003^{d}$ \\
\hline 35 & $0.00 \pm 0.002^{b}$ & $0.00 \pm 0.001^{c}$ & $0.00 \pm 0.001^{e}$ & $0.00 \pm 0.001^{d}$ \\
\hline
\end{tabular}




\section{Appendix}

Appendix Table 1: Nitrate-nitrogen concentration in the reactor at the beginning and end of sampling following a $5 \mathrm{ml} 1000 \mathrm{TAN} / \mathrm{L}$ solution addition.

\begin{tabular}{clll}
\hline $\begin{array}{c}\text { Salinity level } \\
(\%)\end{array}$ & \multicolumn{3}{c}{$\mathbf{1 ~} \mathbf{~ m g ~ T A N} / \mathbf{L}$ spike } \\
\cline { 2 - 4 }$\left[\mathrm{NO}_{3}-\mathrm{N}\right] 10 \mathrm{~min}$ & {$\left[\mathrm{NO}_{3}-\mathrm{N}\right]$ 120 min } & {$\left[\mathrm{NO}_{3}-\mathrm{N}\right]$ rise } \\
\hline Ref. & 39.9 & 40.6 & 0.7 \\
0 & 39.5 & 40.8 & 1.3 \\
5 & 40.4 & 41 & 0.6 \\
10 & 41.2 & 41.7 & 0.5 \\
15 & 40.9 & 41.2 & 0.3 \\
25 & 43.4 & 43.1 & -0.3 \\
35 & 3.2 & 2.6 & -0.6 \\
\hline
\end{tabular}

Appendix Table 2: Nitrate-nitrogen concentration in the reactor at the beginning and end of sampling of a $25-\mathrm{ml} 1000 \mathrm{mg}$ TAN/L or $1000 \mathrm{mg}$ NO2-N/L respectively.

\begin{tabular}{|c|c|c|c|c|c|c|}
\hline \multirow{2}{*}{$\begin{array}{l}\text { Salinity level } \\
(\%)\end{array}$} & \multicolumn{3}{|c|}{$5 \mathrm{mg}$ TAN/L spike } & \multicolumn{3}{|c|}{$5 \mathrm{mg} \mathrm{NO2-N/L} \mathrm{spike}$} \\
\hline & $\begin{array}{l}{\left[\mathrm{NO}_{3}-\mathrm{N}\right]} \\
10 \mathrm{~min}\end{array}$ & $\begin{array}{l}{\left[\mathrm{NO}_{3}-\mathrm{N}\right]} \\
300 \mathrm{~min}\end{array}$ & $\begin{array}{l}{\left[\mathrm{NO}_{3}-\mathrm{N}\right]} \\
\text { rise }\end{array}$ & $\begin{array}{l}{\left[\mathrm{NO}_{3}-\mathrm{N}\right]} \\
10 \mathrm{~min} \\
\end{array}$ & $\begin{array}{l}{\left[\mathrm{NO}_{3}-\mathrm{N}\right]} \\
300 \mathrm{~min}\end{array}$ & $\begin{array}{l}{\left[\mathrm{NO}_{3}-\mathrm{N}\right]} \\
\text { rise }\end{array}$ \\
\hline Ref. & 40.3 & 45.7 & 5.4 & 41.2 & 46 & 4.8 \\
\hline 0 & 40.2 & 45.7 & 5.5 & 40.7 & 45.8 & 5.1 \\
\hline 5 & 41.5 & 45.5 & 4 & 40.5 & 46 & 5.5 \\
\hline 10 & 41.7 & 44.1 & 2.4 & 41.2 & 43.4 & 2.2 \\
\hline 15 & 40.8 & 42.2 & 1.4 & 40.5 & 41.5 & 1 \\
\hline 25 & 42.8 & 43 & 0.2 & 41.1 & 42.7 & 1.6 \\
\hline 35 & 2.5 & 2.6 & 0.1 & 0.6 & 0.7 & 0.1 \\
\hline
\end{tabular}

